\title{
Kinetics of Oil Extraction from Candlenut (Aleurites moluccana)
}

\author{
Faiznur, M.F.* and Wan, A.A.W.A. \\ Faculty of Chemical Engineering, Universiti Teknologi MARA (UiTM), \\ 40450 Shah Alam, Selangor
}

\begin{abstract}
Oil from candlenut (Aleurites moluccana) was extracted using a solvent extraction technique. The influence of three parameters namely extraction time, extraction temperature as well as liquid to solid (L/S) ratio on the candlenut oil yield were studied to optimise the extraction conditions for achieving maximum oil yield. The maximum candlenut oil yield (35.67\%) was achieved using methanol as a solvent at a temperature of $45^{\circ} \mathrm{C}$ for $80 \mathrm{~min}$ of extraction period. The optimum L/S ratio was $10 \mathrm{ml} / \mathrm{g}$. It was found that the candlenut oil yield increases with the increase of extraction time, extraction temperature and L/S ratio. Kinetics of solvent extraction of oil from candlenut was evaluated using Peleg's model and Logarithmic model. The model parameters were calculated using the experimental data. The kinetics of candlenut oil extraction conforms very well to the Peleg's model with a high $R^{2}$ value of 0.9927 and low MRPD value of $1.827 \%$. However, the Logarithmic model can fairly describe the candlenut oil extraction process with the values of $R^{2}$ and MRPD of 0.9653 and $4.352 \%$, respectively.
\end{abstract}

Keywords: Aleurites moluccana; candlenut; kinetics; optimisation; solvent extraction

\section{INTRODUCTION}

Candlenut or Aleurites moluccana is a flowering tree that belongs to the Euphorbiaceae family. In Malaysia, it was commonly known as buah keras nut tree. Apart from candlenut, Aleurites moluccana is also known as Candleberry, Indian Walnut, Varnish tree, Kukui and Kamiri nut tree, depending on the region (Siddique et al., 2011). Candlenut trees are native to the Molucca Islands and widely found in South East Asia (Norulaini et al., 2004). It has been spread throughout the tropical Pacific because of the high oil content in the seeds, which was around 50\%. The candlenut oil has been used for thousands of years by Polynesians as a moisturiser since it contains essential fatty acids such as linoleic and linolenic acids that are beneficial to healthy skin. In the pharmaceutical industry, it is used for treating numerous skin diseases such as eczema, psoriasis and burned skin. It is effective in repairing damaged skin. Candlenut oil is also an excellent ingredient in the making of soap, lotion, creams, balms, scrubs or used in massage oils. This candlenut oil is widely used in the cosmetics industry and might currently be candlenut primary commercial product. It is also used as a varnish and in the preservation of fishing nets. Recently, candlenut seed is being exploited as a potential feedstock for biodiesel (Sulistyo et al., 2009).

Isolation of vegetable oil involved several approaches from the ancient time until today. Various methods are used including mechanical pressing, maceration, effleurage extraction, solvent extraction, steam distillation, ultrasonic and supercritical fluid extraction. The method chosen depends on the ease with which the substances can be removed from the plant material, the types of plant material and the costs involved in extracting the substances. Solvent extraction is one of the typical methods of extracting vegetable oil from oilseeds (Ricardo Cardoso et al., 2013). In this method, the solid sample is immersed in a suitable solvent and the extracted oil is collected after the equilibrium extraction is reached (Chan et al., 2014). Generally, solvents such as hexane, ethanol, methanol, 
petroleum ether and acetone are used in the extraction of oil from oilseeds (Mani et al., 2007). Solvent extraction is considered as one of the cheapest and most efficient technique in producing oil from many types of seed such as jojoba, soybean, palm and jatropha (Dutta et al., 2014).

The mathematical kinetic model is powerful engineering tools which greatly facilitate optimisation, simulation and design of an extraction process (Jokić et al., 2010). They are also useful in the development of scaling-up procedures from bench to pilot and industrial scales (Ayas and Yilmaz, 2014). Kinetic models such as power-law and parabolic diffusion models have been used in the extraction study involving numerous target compounds from different types of solid materials (Ghasemi-Fasaei et al., 2012; Das and Bera, 2013; Yaneva et al., 2013). Other than that, secondorder model (Kusuma and Mahfud, 2018; Goula, 2013), Sovová model (Piva et al., 2018), Peleg's model (Vetal et al., 2013) as well as Ponomaryov's empirical equation (Veličković et al., 2006) have been widely used in modelling various solid-liquid extraction processes. The semi-empirical kinetic model introduced by Peleg is widely used to explain the extraction curves of biological materials from plant sources because of the similarity to the shape of sorption curves (Vetal et al., 2013). Kinetic modelling provides a theoretical description of the process behaviour and evaluation of the mass transfer coefficients (Simeonov and Koleva, 2012). A model that fits the experimental data is used to determine the diffusion coefficients which are required to describe and optimise the process, thus providing a better understanding of the complex diffusion mechanism (Winitsorn et al., 2008). To date, the evaluation of kinetics on oil extraction from candlenut has not been reported in the literature.

This study aims to investigate the influence of extraction time, extraction temperature and $\mathrm{L} / \mathrm{S}$ ratio on the extraction yield of candlenut oil. The kinetics behaviour of oil extraction from candlenut was then evaluated using Peleg's model and Logarithmic model. The best-suited model will be determined accordingly. Meanwhile, the experimental data obtained will be used to establish the kinetics of the oil extraction process.

\section{MATERIALS AND METHODS}

\section{A. Candlenut Oil Extraction}

500 of fresh candlenut were purchased from a market located in Shah Alam, Selangor. They were cleaned and stored at ambient temperature. Before oil extraction, the candlenut was ground using a dry mill and sieved through a sieve shaker of pore size $850 \mu \mathrm{m}$. The sample with particle size of $850 \mu \mathrm{m}$ and below was used in this study. Methanol was used as a solvent. The candlenut sample (5g) and methanol were mixed in a conical flask $(125 \mathrm{ml})$, which was then covered with aluminium foil. It is then placed on a hot plate to heat the extraction mixture to the desired temperature. A magnetic stirrer was placed in the extraction mixture to promote mixing. After the extraction process was completed, the oil extract was centrifuged at 4,0oorpm for $20 \mathrm{~min}$ to separate the liquid extract from the solid residue. Subsequently, the solvent was removed from the liquid extract using a rotary evaporator (Heidolph). The extracted oil obtained was placed in a desiccator to remove any moisture and weighed until a constant weight was reached. In this study, the extraction time, extraction temperature as well as $\mathrm{L} / \mathrm{S}$ ratio was varied from $5^{-120} \mathrm{~min}, 25^{\circ} \mathrm{C}-55^{\circ} \mathrm{C}$

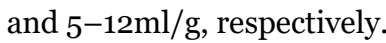

\section{B. Candlenut Oil Yield}

Extraction yield of candlenut oil was calculated using Equation [1]

$$
Y=\frac{M_{1}}{M_{0}} \times 100 \%
$$

where $Y$ is the extraction yield of candlenut oil (\%), $M_{1}$ is the mass of candlenut oil extracted from the sample $(\mathrm{g})$, and $M_{O}$ is the mass of the candlenut sample used (g).

\section{Mathematical Model}

The kinetic behaviour of the oil extraction process from candlenut was evaluated using Peleg's model and Logarithmic model. The kinetic parameters for both models were calculated numerically with a non-linear regression using Polymath Software 5.0. 


\section{Peleg's Model}

Peleg's model, which is used for the description of sorption curves, was adapted for the description of the candlenut oil extraction process. The expression for Peleg's model is

$$
y(t)=y_{o}+\frac{t}{K_{1}+K_{2} t}
$$

where $y(t)$ represents the oil yield at time $t, K_{1}$ is Peleg's rate constant (relates to extraction rate at the very beginning of the extraction process), $\mathrm{K}_{2}$ is Peleg's capacity constant (relates to maximum extraction yield during the extraction process) and $y_{0}$ is the oil yield at time $t=0$. At $t=0, y_{0}$ value equals zero, and thus Equation [2] can be reduced to

$$
y(t)=\frac{t}{K_{1}+K_{2} t}
$$

\section{E. Logarithmic Model}

The logarithmic model was used as follows

$$
y(t)=a \log t+b
$$

where $\mathrm{a}$ and $\mathrm{b}$ are logarithmic model constants, and $y(t)$ represents the oil yield at time $t$.

\section{F. Statistical Analysis}

The validation of kinetic models was done by evaluating the differences between the experimental and predicted oil yield via determination coefficient, $R^{2}$. In addition, the goodness-of-fit of the model was further evaluated using the mean relative percentage deviation (MRPD) value. It is defined in Equation [5]

$$
\operatorname{MRPD}(\%)=\frac{100}{N} \times \sum \frac{\left|Y-Y_{P}\right|}{Y}
$$

where $\mathrm{Y}$ and $\mathrm{Y}_{\mathrm{P}}$ are the experimental and predicted yield of candlenut oil, respectively, and $\mathrm{N}$ is the number of experimental data. A mathematical model is considered acceptable to be used in describing an extraction process if the MRPD value is less than 10\% (Kaymak-Ertekin and Gedik, 2004).

\section{RESULTS AND DISCUSSIONS}

\section{A. Effect of Extraction Time}

Figure 1 shows the effect of extraction time on the candlenut oil yield at a temperature of $30^{\circ} \mathrm{C}$ and $\mathrm{L} / \mathrm{S}$ ratio of $10 \mathrm{ml} / \mathrm{g}$. It can be seen that the yield increased rapidly from $14.81 \%$ to 29.66\% within the first $40 \mathrm{~min}$ of extraction period. As the extraction time prolonged until $80 \mathrm{~min}$, the oil yield continues to increase gradually from $29.66 \%$ to $32.89 \%$. However, beyond $80 \mathrm{~min}$, the change in oil yield is no longer significant.

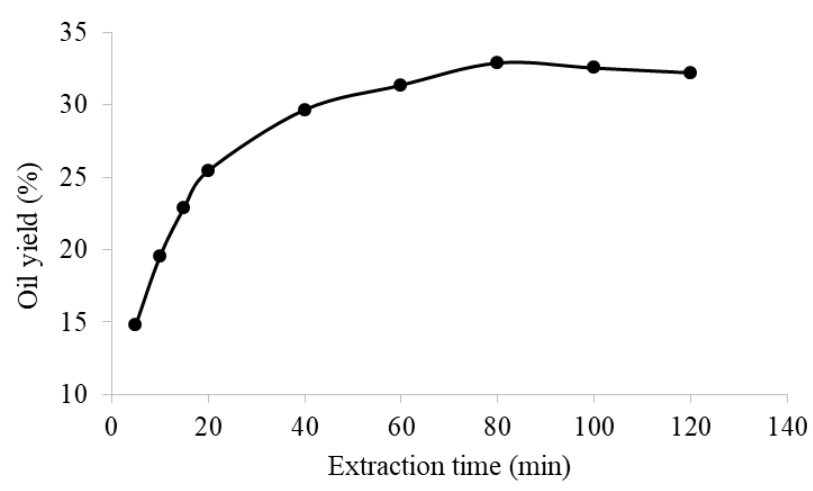

Figure 1. Effect of different extraction time on candlenut oil yield (extraction temperature $30^{\circ} \mathrm{C}, \mathrm{L} / \mathrm{S}$ ratio $10 \mathrm{ml} / \mathrm{g}$ and methanol as a solvent)

Therefore, the optimum extraction time to achieve the maximum yield of candlenut oil (32.89\%) was found to be 80 min. According to Goula (2013), this could be because the extraction processes occurred in two stages; the first stage which is characterised by a rapid rate, involved solvent penetration into the cellular structure followed by the dissolution of soluble constituents in the solvent. This is also known as a washing stage. The second stage, better known as a slow diffusion stage, involved the external diffusion of soluble constituents through the porous structure of the residual solid and its transfer from the solution in contact with the particles to the bulk solution. The oil yield does not 
show any significant changes after $80 \mathrm{~min}$.

A similar result was also obtained by $\mathrm{Hu}$ et al. (2012) in their study on safflower seed oil extraction. The extraction yield increased with time and reached a maximum value at 30 min. After that, it increased a little. During this stage, the osmotic pressure balanced the solution system and the insignificant increase of extraction yield after a certain extent shows that an equilibrium condition was achieved in the solvent (Norshazila et al., 2017). Therefore, extending the extraction time will not increase the oil yield further.

\section{B. Effect of Extraction Temperature}

The effect of extraction temperature towards the candlenut oil yield is shown in Figure 2. During this experiment, both extraction time and $\mathrm{L} / \mathrm{S}$ ratio were kept constant at $80 \mathrm{~min}$ and $10 \mathrm{ml} / \mathrm{g}$, respectively. It was observed that the increment of temperature from 25 to $45^{\circ} \mathrm{C}$ had improved the oil yield from $31.26 \%$ to $35.67 \%$, but when the temperature was raised to $55^{\circ} \mathrm{C}$, the oil yield dropped gradually to $34.55 \%$.

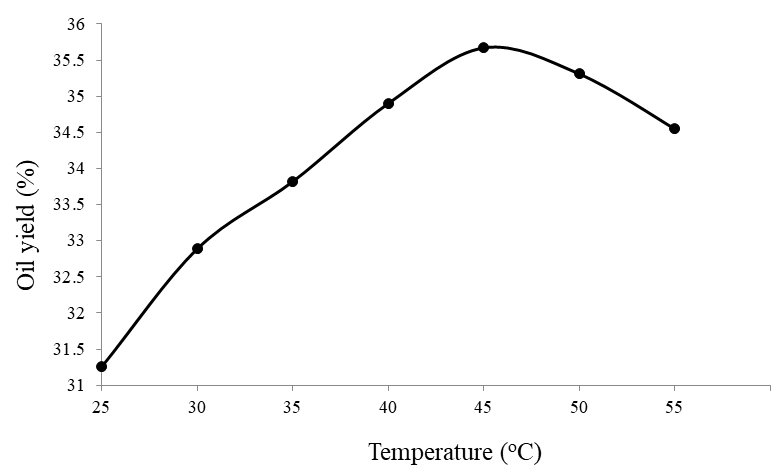

Figure 2. Effect of different temperature on candlenut oil yield (extraction time $80 \mathrm{~min}, \mathrm{~L} / \mathrm{S}$ ratio $10 \mathrm{ml} / \mathrm{g}$ and methanol as a solvent)

This observation can be attributed to the fact that the temperature affected many physical properties such as viscosity, diffusivity, solubility, vapour pressure and surface tension. Liquid with lower viscosity has high diffusivity. Therefore it could easily be diffused into the pores of the solute (Hemwimol et al., 2006). Besides that, the extraction yield was found to increase with increasing temperature due to the increased solubility of the oil in the solvent. In addition, at a higher temperature, the liquid viscosity and density decreased, thus resulting in increased mass transfer (Toma et al., 2001; Palma and Barroso, 2002).

On the other hand, the oil yield started to decrease when the temperature was further raised to $55^{\circ} \mathrm{C}$. This might be due to the decomposition of active ingredients presents in the oil (Bhutada et al., 2016). Abdullah et al. (2017) reported the same finding in their study on the effect of temperature on the microalgae oil extraction. The extraction temperature was varied over the range of $55^{\circ} \mathrm{C}$ to $75^{\circ} \mathrm{C}$. The increase in temperature from $55^{\circ} \mathrm{C}$ to $65^{\circ} \mathrm{C}$ leads to an increase in the oil extraction yield from $47.29 \%$ to $56.92 \%$ while increasing the temperature from $65^{\circ} \mathrm{C}$ to $75^{\circ} \mathrm{C}$ resulted in a decrease in the oil yield from $56.92 \%$ to $52.26 \%$. The maximum candlenut oil yield (35.67\%) is achieved at an optimum extraction temperature of $45^{\circ} \mathrm{C}$.

\section{Effect of Liquid-to-Solid Ratio}

The relationship between the oil yield and L/S ratio is shown in Figure 3. The extraction temperature and time were kept constant at $45^{\circ} \mathrm{C}$ and $80 \mathrm{~min}$. The oil yield increases from $31.64 \%$ to $35.67 \%$ as the L/S ratio increases gradually from 5 to $10 \mathrm{ml} / \mathrm{g}$. This increasing trend of oil yield is due to the increasing rate of oil diffusion caused by a higher $\mathrm{L} / \mathrm{S}$ ratio. A high L/S ratio increases the concentration gradient, and therefore, increases the rate of diffusion. These results are consistent with the mass transfer principles whereby a greater concentration gradient promotes a greater driving force (Norshazila et al., 2017). However, the oil yield did not show any significant increment when the L/S ratio is further raised to $12 \mathrm{ml} / \mathrm{g}$. According to Nyamien et al. (2015), this might be due to the saturation phenomenon whereby, when the solvent is saturated with bioactive components, the cellular phenomenon of diffusion stops as the equilibrium is achieved. Since the equilibrium is reached at L/S ratio of $10 \mathrm{ml} / \mathrm{g}$, the oil yield does not increase after that. A similar trend was observed by Tan et al. (2011) in their study on the extraction of antioxidant compounds from Centella asiatica. The solid to solvent ratio was manipulated from 1:5 to 1:20, and it was reported that the maximum total phenolic and flavonoid contents were achieved at a solid to solvent ratio 
of $1: 15$. In this study, the optimum $\mathrm{L} / \mathrm{S}$ ratio to obtain a maximum oil yield ( $35.67 \%)$ is $10 \mathrm{ml} / \mathrm{g}$.

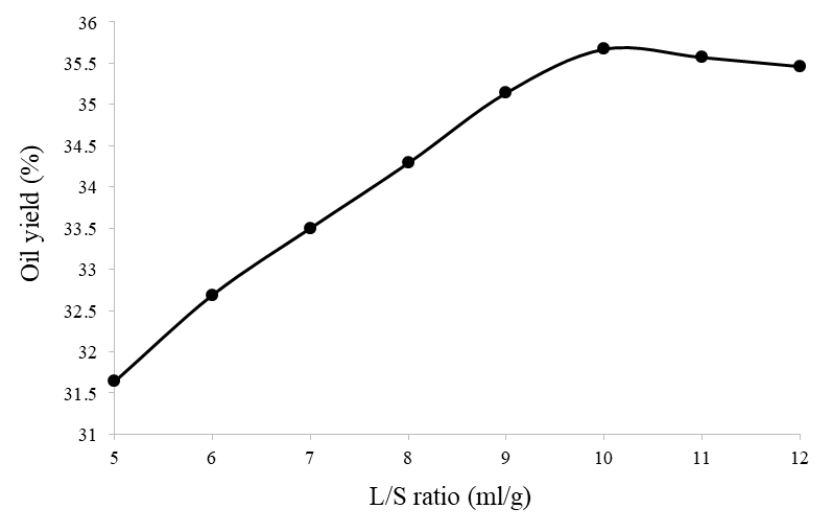

Figure 3. Effect of different L/S ratio on oil yield (extraction temperature $45^{\circ} \mathrm{C}$, extraction time 80 min and methanol as a solvent)

\section{Kinetics of Candlenut Oil Extraction}

The profiles for experimental (represented by symbols) and simulated (represented by lines) oil yield for Peleg's model and Logarithmic model are shown in Figure 4 and Figure 5, respectively. As can be seen, Peleg's model fits the experimental data better than the Logarithmic model. The Peleg's model fit the experimental data in both stages of extraction, namely the washing part and the slow extraction. The washing part occurs at the earlier stage of extraction, from 5 to $40 \mathrm{~min}$ while the slow extraction occurs at $40 \mathrm{~min}$ of extraction time onwards. The values of kinetic parameters $K_{1}, K_{2}, a$ and $b$ are shown in Table 1 . In order to validate the kinetic model used, the values of $R^{2}$ and MRPD were calculated accordingly. Peleg's model shows a good agreement with the experimental data as the value of $R^{2}$ and MRPD are 0.9927 and $1.827 \%$, respectively. These values indicate that Peleg's model is suitable to be used in describing the extraction of candlenut oil. On the other hand, Logarithmic model shows fair agreement with the experimental data obtained as the value of $R^{2}(0.9603)$ is slightly lower than that of Peleg's model. Furthermore, MRPD for Logarithmic model (4.352\%) is higher than that of Peleg's model.

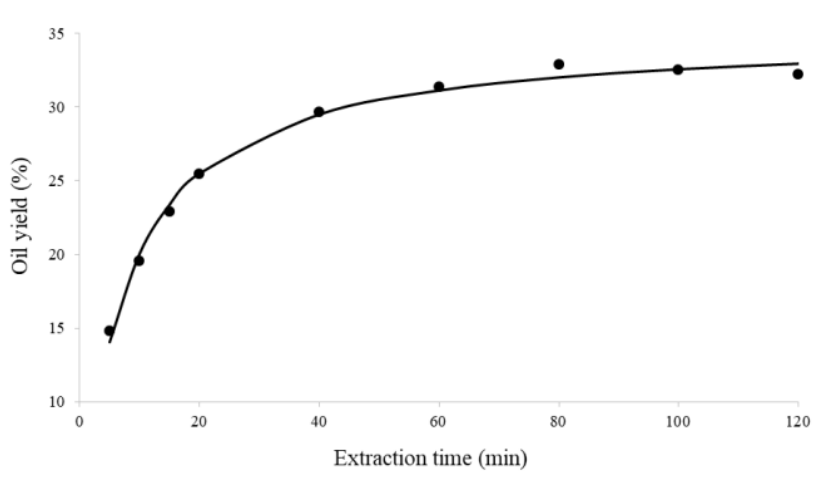

Figure 4. The experimental and simulated oil yield for Peleg's model

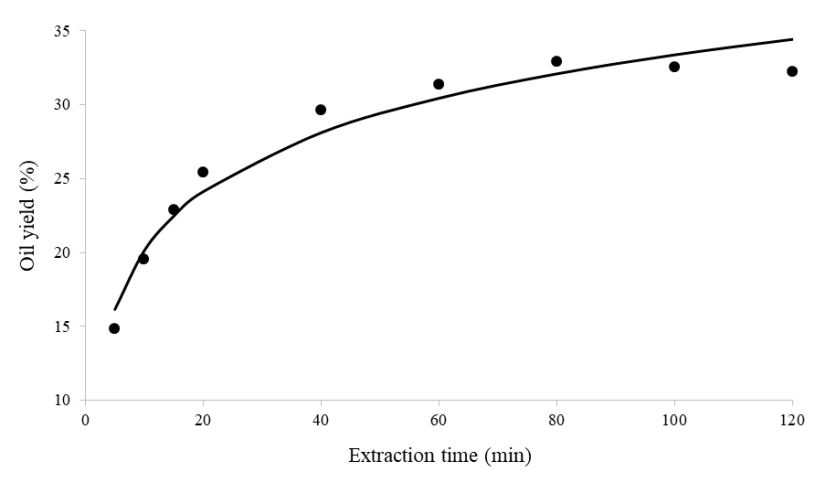

Figure 5. The experimental and simulated oil yield for Logarithmic model

\section{CONCLUSION}

In this study, the oil from candlenut was extracted by using the solvent extraction technique. The effects of extraction time, extraction temperature and L/S ratio were evaluated. The oil yield increased with increasing extraction time, extraction temperature, as well as $\mathrm{L} / \mathrm{S}$ ratio. The kinetics of candlenut oil extraction was studied using Peleg's model and Logarithmic model. The results showed that both models could be used to describe the extraction process with high values of $R^{2}$ and low MRPD values. However, Peleg's model fits the experimental data better than the Logarithmic model with a higher value of $R^{2}$ (0.9927) and lower value of MRPD (1.827\%). Therefore, Peleg's model is more suitable to be used in describing the kinetic behaviour of candlenut oil extraction.

Table 1. Kinetic model parameters for Peleg's and Logarithmic models 


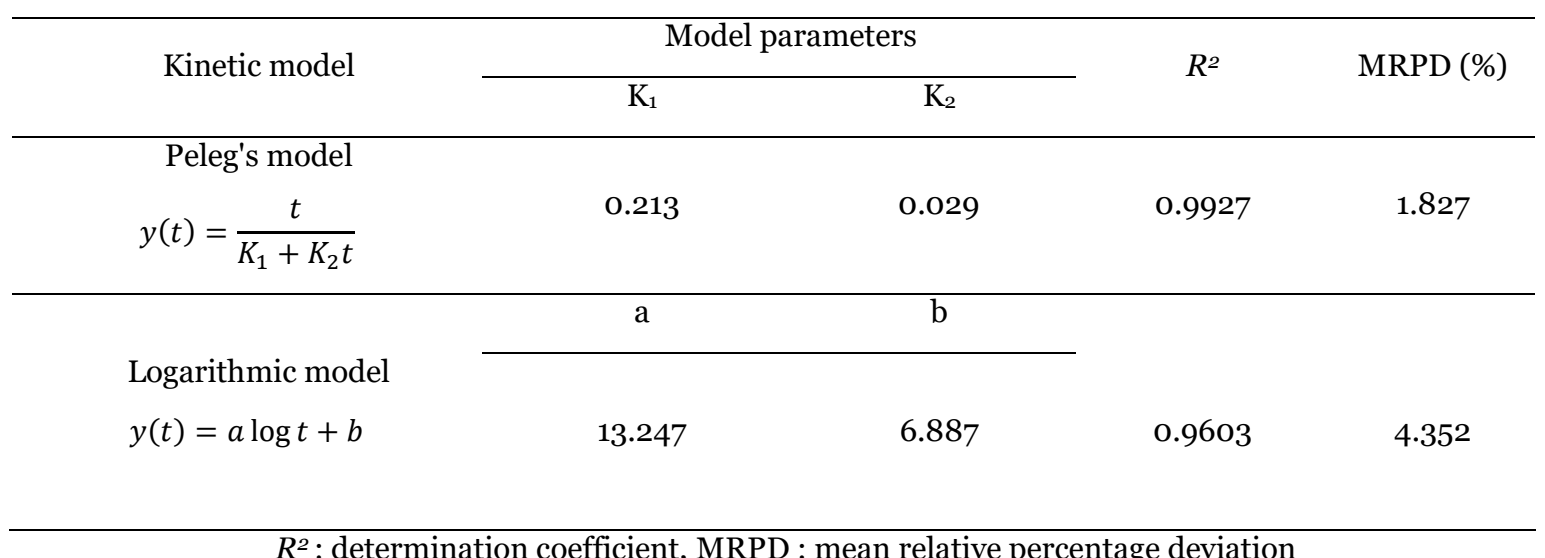

$R^{2}$ : determination coefficient, MRPD : mean relative percentage deviation

\section{ACKNOWLEDGEMENTS}

This research was fully supported by the Faculty of Chemical Engineering, Universiti Teknologi MARA (UiTM) Shah Alam, Selangor. The authors are grateful for the support provided.

\section{REFERENCES}

[1] Abdullah, N, Amran, NA \& Yasin, NHM 2017, 'Algae oil extraction from freshwater microalgae Chlorella vulgaris', Malaysian Journal of Analytical Sciences, vol. 21, no. 3, pp. 735-744.

[2] Ayas, N \& Yilmaz, O 2014, 'A shrinking core model and empirical kinetic approaches in supercritical $\mathrm{CO} 2$ extraction of safflower seed oil', The Journal of Supercritical Fluids, vol. 94, pp. 81-90.

[3] Bhutada, PR, Jadhav, AJ, Pinjari, DV, Nemade, PR \& Jain, RD 2016, 'Solvent assisted extraction of oil from Moringa oleifera Lam. seeds', Industrial Crops and Products, vol. 82, pp. 74-80.

[4] Chan, C-H, Yusoff, R \& Ngoh, G-C 2014, 'Modeling and kinetics study of conventional and assisted batch solvent extraction', Chemical Engineering Research and Design, vol. 92, no. 6, pp. 1169-1186.
[5] Das, S Bera, D 2013, 'Mathematical model study on solvent extraction of carotene from carrot', International Journal of Research in Engineering and Technology, vol. 2, no. 9, pp. 343-349.

[6] Dutta, R, Sarkar, U \& Mukherjee, A 2014, 'Extraction of oil from Crotalaria Juncea seeds in a modified Soxhlet apparatus: Physical and chemical characterization of a prospective bio-fuel', Fuel, vol. 116, no. o, pp. 794-802.

[7] Ghasemi-Fasaei, R, Ronaghi, A \& Ghiri, MN 2012, 'Time-dependent copper extraction in different soil orders as influenced by soil to extractant ratio', International Research Journal of Applied and Basic Sciences, vol. 3, no. 8, pp. 1683-169o.

[8] Goula, AM 2013, 'Ultrasound-assisted extraction of pomegranate seed oil - Kinetic modeling', Journal of Food Engineering, vol. 117, no. 4, pp. 492-498. 
[9] Hemwimol, S, Pavasant, P \& Shotipruk, A 2006, 'Ultrasound-assisted extraction of anthraquinones from roots of Morinda citrifolia', Ultrasonics Sonochemistry, vol. 13, no. 6, pp. 543-548.

[10] Hu, AJ, Feng, QQ, Zheng, J, Hu, XH, Wu, C \& Liu, C-Y 2012, 'Kinetic model and technology of ultrasound extraction of safflower seed oil', Journal of Food Process Engineering, vol. 35, no. 2, pp. 278-294.

[11] Jokić, S, Velić, D, Bilić, M, Bucić-Kojić, A, Planinić, M \& Tomas, S 2010, 'Modelling of the process of solid-liquid extraction of total polyphenols from soybeans', Czech Journal of Food Science, vol. 28, no. 3, pp. 206-212.

[12] Kaymak-Ertekin, F \& Gedik, A 2004, 'Sorption isotherms and isosteric heat of sorption for grapes, apricots, apples and potatoes', $L W T$ - Food Science and Technology, vol. 37, no. 4, pp. 429-438.

[13] Kusuma, HS \& Mahfud, M 2018, 'Kinetic studies on extraction of essential oil from sandalwood (Santalum album) by microwave airhydrodistillation method', Alexandria Engineering Journal, vol. 57, no. 2, pp. 1163-1172.

[14] Mani, S, Jaya, S \& Vadivambal, R 2007, 'Optimization of solvent extraction of moringa (Moringa oleifera) seed kernel oil using response surface methodology', Food and Bioproducts Processing, vol. 85, no. 4, pp. 328-335.

[15] Norshazila, S, Koy, CN, Rashidi, O, Ho, LH, Azrina, I, Zaizuliana, RAN \& Zarinah, Z 2017, 'The Effect of Time, Temperature and Solid to Solvent Ratio on Pumpkin Carotenoids Extracted Using Food Grade Solvents', Sains Malaysiana, vol. 46, no. 2, pp. 231-237.
[16] Norulaini, NAN, Budi, RS, Omar, A, Zaidul, LSM \& Omar, AKM 2004, 'Major Chemical Constituents of Candle Nut Oil Extract Using Supercritical Carbon Dioxide', Malaysian Journal of Pharmaceutical Sciences, vol. 2, no. 1, pp. 61-72.

[17] Nyamien, Y, Adjé, F, Niamké, F, Koffi, E, Chatigre, O, Adima, A \& Biego, HG 2015, 'Effect of Solvents and Solid-Liquid Ratio on Caffeine Extraction from Côte d'Ivoire Kola Nuts (Cola nitida)', International Journal of Science and Research, vol. 4, no. 1, pp. 218-222.

[18] Palma, M \& Barroso, CG 2002, 'Ultrasoundassisted extraction and determination of tartaric and malic acids from grapes and winemaking byproducts', Analytica Chimica Acta, vol. 458, no. pp. 119-130.

[19] Piva, GS, Weschenfelder, TA, Franceschi, E, Cansian, RL, Paroul, N \& Steffens, C 2018, 'Extraction and modeling of flaxseed (Linnum usitatissimum) oil using subcritical propane', Journal of Food Engineering, vol. 228, no. pp. 5056.

[20] Ricardo Cardoso, dO, Sueli Teresa Davantel, dB \& Gimenes, ML 2013, 'The extraction of passion fruit oil with green solvents', Journal of Food Engineering, vol. 117, no. 4, pp. 458-463.

[21] Siddique, BM, Ahmad, A, Alkarkhi, AFM, Ibrahim, MH \& Omar, AKM 2011, 'Chemical Composition and Antioxidant Properties of Candlenut Oil Extracted by Supercritical CO2', Journal of Food Science, vol. 76, no. 4, pp. 535-542.

[22] Simeonov, E \& Koleva, V 2012, 'Solid-liquid extraction of tannins from Geranium sanguineum L. - Experimental kinetics and modelling', 
Chemical and Biochemical Engineering

Quarterly, vol. 26, no. 3, pp. 249-255.

[23] Sulistyo, H, Rahayu, SS, Suardjaja, IM \& Setiadi, UH 2009, 'Crude Candlenut Oil Ethanolysis to Produce Renewable Energy at Ambient Condition', in Proceedings of the World Congress on Engineering and Computer Science, San Francisco, USA, 85-88.

[24] Tan, PW, Tan, CP \& Ho, CW 2011, 'Antioxidant properties: Effects of solid-to-solvent ratio on antioxidant compounds and capacities of Pegaga (Centella asiatica)', International Food Research Journal, vol. 18, no. pp. 557-562.

[25] Toma, M, Vinatoru, M, Paniwnyk, L \& Mason, TJ 2001, 'Investigation of the effects of ultrasound on vegetal tissues during solvent extraction', Ultrasonics Sonochemistry, vol. 8, no. pp. 137-142.

[26] Veličković, DT, Milenović, DM, Ristić, MS \& Veljković, VB 2006, 'Kinetics of ultrasonic extraction of extractive substances from garden (Salvia officinalis L.) and glutinous (Salvia glutinosa L.) sage', Ultrasonics Sonochemistry, vol. 13 , no. 2 , pp. 150-156.

[27] Vetal, MD, Lade, VG \& Rathod, VK 2013, 'Extraction of ursolic acid from Ocimum sanctum by ultrasound: Process intensification and kinetic studies', Chemical Engineering and Processing: Process Intensification, vol. 69, no. pp. 24-30.

[28] Winitsorn, A, Douglas, PL, Douglas, S, Pongampai, S \& Teppaitoon, W 2008, 'Modeling the Extraction of Valuable Substances from Natural Plants Using Solid-Liquid Extraction', Chemical Engineering Communications, vol. 195, no. pp. 1457-1464.

[29] Yaneva, ZL, Koumanova, BK \& Allen, SJ 2013, 'Applicability comparison of different kinetic/diffusion models for 4-nitrophenol sorption on Rhizopus oryzae dead biomass', Bulgarian Chemical Communications, vol. 45, no. 2, pp. 161 168. 